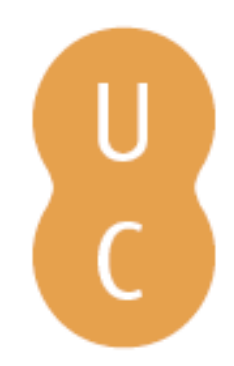

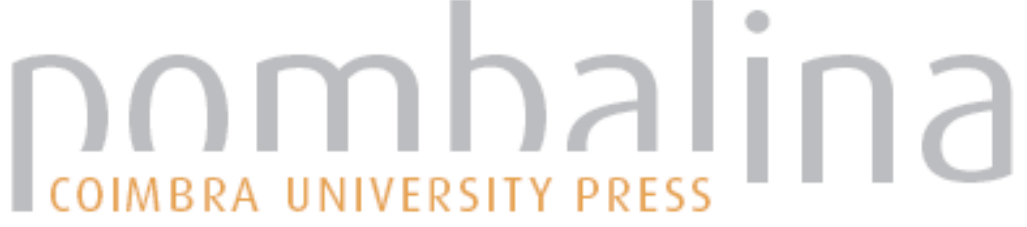

\section{Importance of values in the coaching process}

\author{
Autor(es): Lee, Martin J.
}

Publicado por: Imprensa da Universidade de Coimbra

URL

persistente: $\quad$ URI:http://hdl.handle.net/10316.2/38868

DOI: $\quad$ DOI:http://dx.doi.org/10.14195/978-989-26-1171-6_5

Accessed : $\quad$ 26-Apr-2023 13:36:16

A navegação consulta e descarregamento dos títulos inseridos nas Bibliotecas Digitais UC Digitalis, UC Pombalina e UC Impactum, pressupõem a aceitação plena e sem reservas dos Termos e Condições de Uso destas Bibliotecas Digitais, disponíveis em https://digitalis.uc.pt/pt-pt/termos.

Conforme exposto nos referidos Termos e Condições de Uso, o descarregamento de títulos de acesso restrito requer uma licença válida de autorização devendo o utilizador aceder ao(s) documento(s) a partir de um endereço de IP da instituição detentora da supramencionada licença.

Ao utilizador é apenas permitido o descarregamento para uso pessoal, pelo que o emprego do(s) título(s) descarregado(s) para outro fim, designadamente comercial, carece de autorização do respetivo autor ou editor da obra.

Na medida em que todas as obras da UC Digitalis se encontram protegidas pelo Código do Direito de Autor e Direitos Conexos e demais legislação aplicável, toda a cópia, parcial ou total, deste documento, nos casos em que é legalmente admitida, deverá conter ou fazer-se acompanhar por este aviso.

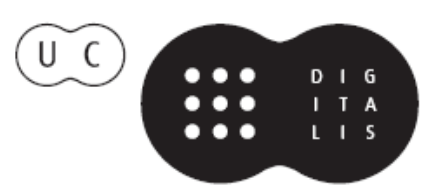



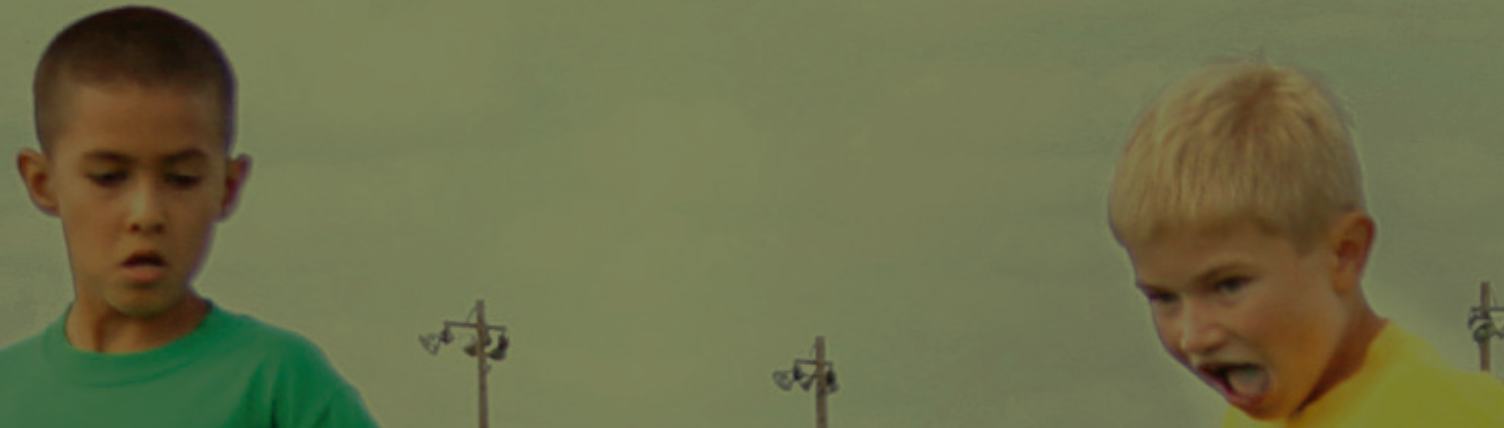

YOUTH SPORTS

\section{PARTICIPATION, $:$}

TRAINABHLTY TY

AND READINESSh

MANUEL J. COELHO E SILVA

ANTÓNIO J. FIGUEIREDO

MARIJE T. ELFERINK-GEMSER

ROBERT M. MALINA

EDITORS

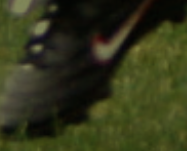

2. ${ }^{\circ}$ EDIÇÃO

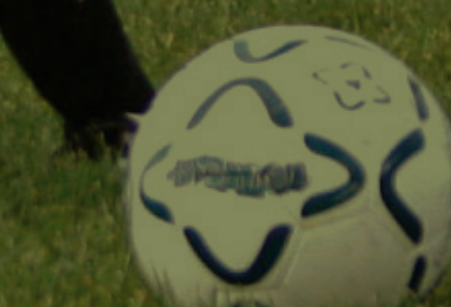

IMPRENSA DA

UNIVERSIDADE

DE COIMBRA

COIMBRA

UNIVERSITY

PRESS 


\section{CHAPTER 5: IMPORTANCE OF VALUES IN THE COACHING PROCESS}

Martin J Lee [†]

\section{INTRODUCTION}

The subject of this paper is values in coaching and their role in the coaching process; I will address most of my remarks specifically to the coaching of children. My purpose is to encourage coaches to develop a personal philosophy of coaching that emphasises the well-being of the children under their care. Children are vulnerable to a variety of adult influences and sport provides many opportunities for them to be exploited to meet the needs of other people, even to the extent of child abuse (see for example, Ryan, 1995). For children to get the most out of the sporting experience coaches need to consider carefully how they can best serve primarily the needs of the children while at the same time meeting their own needs and those of the sport and clubs which they represent. Naturally there is a potential for considerable conflict here since the young athletes, coaches, clubs, sport governing bodies, and parents may all have differing ideas about the purposes of sport and the desirability of specific practices.

You may have asked yourselves why we provide sport for children. If so, you have probably also asked why you are part of the process. These questions are very important because coaching children is a great responsibility. Coaches have a great impact not only on how children experience sport but also because children's attitudes, toward both themselves and the world, are not fixed but still forming, and coaches have an effect on their development.

Knowing clearly what part you are going to play in providing sport experiences for children is a matter of having a personal philosophy, a set of values which guides the things you do to present the sport to the children you coach. You need to be aware of what it is that you are really trying to do, and that it fits what the children need and want.

\section{a) Patterns of growth and participation in youth sport}

Population changes and participation patterns among children affect how sports federations promote their own sports and retain the interest of young 
people. They also raise questions about the role that sport plays in children's lives and who are the main beneficiaries of youth sport programmes.

Sports federations sometimes worry that children drop out of sport during their teenage years, often when they are between 14 and 16 years old. Surveys have shown that the number of teenagers who do sport regularly decreases with age. The reasons for their dropping out may be many but perhaps we should ask whether it is necessarily a "bad thing". Some research shows that children drop out of some activities so that they can spend more time on other activities - including other sports, the demands of school work, lack of the pleasure that the sport gives them, and lack of success, (see Brustad, 1993; Whitehead, 1993).

Dropping out of sport may matter because it stops the development of a pattern of activity that may benefit peoples' health throughout their lives. Some coaches and administrators think that it is always a bad thing for children to drop out of sport - or even to move on to a better team. But it may be the best thing for the children and their progress in life if they have something better to do. Nevertheless, the sporting experience may have still provided valuable self-knowledge and personal satisfaction.

Certainly, at least in the UK, it is plausible to conclude that while children take up sport in late childhood many drop out during midadolescence. It may not be coincidental that this period is associated with increased pressure to succeed in public academic examinations. Indeed children may be placed in a position where they must consider the relative benefits of trying to succeed in both their studies and sport and be forced to emphasise one at the expense of the other. Further, as young athletes become more proficient they experience a need to specialise in fewer sports than they began. Hence, many of those who drop out of one will continue to participate in others (Tasmanian State School Sports Council, 1983).

\section{b) Aims of youth sport provision}

Children's reasons for doing sport may be different from those of the providers - governments, federations, clubs, coaches, parents etc. Each of these groups has its own goals that may not take account of what is most important or what is most beneficial to children. For them, having fun, learning new skills, and being with friends as well as competition are among the most important things (see Weiss, 1993). They do not necessarily do it to win medals or develop social skills, although these things may come out it. To work successfully with children coaches need to keep this in mind; then their players will keep coming back and they can advance their skills and help them to become better performers. Sport, as adults know it, is not part of their 
world until we make it so. For children, if the fun stops there is little point in being there!

\section{SPORT IN MODERN SOCIETY}

It is important to distinguish between the value of sport to a society and the values that exist within a sporting culture. Rokeach (1973) made an important clarification of the term 'value' in a seminal discussion of the concept. He drew attention to the different ways in which the word value was used first to express the value that an object is said to have and second to express the value that an individual is said to hold or adhere to. So, for example, a footballer may be of particular value to his team as a striker and be worth several million euros. But that footballer may hold values to do with winning, or achievement, or with honesty, team spirit, and playing by the rules. These are motivating forces that determine how he will play the game. In the former sense, sport may be of value to a society by providing certain good things to it, much as our striker provides goals. These values may be thought of as functions, although they are not the explicit reasons for doing sport

In this sense, sport provides a wide range of functions in contemporary society. The values of sport have been widely considered by sports philosophers and sociologists who have variously considered that sport provides opportunities for élitism, nationalism, economic growth and education to name but a few (see for example Tannsjo and Tamburrini, 2000; Glassford, 1989).

Elitism: In Western capitalist democracies, societies reward achievement through skill and hard work. Those who do not succeed are frequently disadvantaged. In sport, this may be reflected in a philosophy of retaining only those who are winners, the others are discarded. In a recent argument, Tannsjo (2000) suggested that sport encourages the fascist values of admiration of strength and contempt for weakness. He believes that this is particularly true of individual sports, such as those that take pride of place in the Olympic Games, where spectators can be overwhelmed by demonstrations of superiority. While the fascist conclusion may be challenged, there remains the problem of the admiration of the élite by fans leading to a decline in participation as viewing excellence becomes more readily available to spectators. This has recently been exemplified in the UK by the loss of television revenue due to low viewing numbers for lesser football leagues; this has resulted in the loss of jobs for players and threats to the existence of clubs. The pursuit of élitism, which increasingly drives sport as a business, even suggests that advances in gene therapy might eventually result in the production of athletes to order (Bouchard, 1999; Munthe, 2000). 
Nationalism: Allied to the pursuit of superiority is the role of sport in the promotion of national identity and esteem. We have become accustomed to the display of national fervour at international sporting events. The idea that sport provides an acceptable way to display international rivalries, even hostilities, has become commonplace (Chataway and Goodhart, 1968; Dixon, 2000). Morgan (2000) has suggested that this is even more potent where sport provides the means for underprivileged nations to establish their identity and independence from former colonists. The power of World Cups and Olympic Games is such that citizens may feel good or bad according to how their representatives perform sometimes with tragic effects. In some cases, such as East Germany prior to 1989, young athletes may be subjected to controlled drug programmes designed to enhance their performance in the interests of the state (Franke and Berendonk, 1997).

Commercialism: In a similar way children provide the raw material for the progress of the sport industry. Sport is now a major part of the leisure and entertainment business with global companies in the form of sports, such as Formula One, or of clubs, such as Manchester United, being marketed like any other commercial product. In order to survive sports and clubs must be able to demonstrate and sustain excellence. In the United Kingdom (UK), sport provides over 400,000 full time jobs and another 108,000 full-time equivalent jobs among volunteers. The value added to the UK economy in 1995 was $£ 9.8$ billion, twice the value in 1985 and sponsorship was estimated at $£ 404$ million in 2000 (Sport England, 2002). An industry of this magnitude requires both the effective selection of raw material and product development to sustain it. Consequently those who cannot meet the standards required are rejected and young people who cannot make the grade may be discouraged to the point of giving up altogether. In this sense children are the raw material, once again, and the search for talented athletes who can be identified and signed up early becomes ever more intense.

Talent identification: Coaches have an important role in the process of the identification and development of potentially élite performers for commercial and nationalistic purposes. While the value, or importance, of sport in these fields is undeniable and laudable, the process puts coaches in the delicate position of balancing the needs of companies or governments with the individual needs of children. The $18^{\text {th }}$ century philosopher, Immanuel Kant, proposed a number of imperatives about human behaviour, one of which is that no person should be the means to another's ends. In other words, it is morally wrong to exploit others for our own purposes. And yet, in the world of sport, this is increasingly difficult to avoid. Sport becomes a saucepan for cooking young people in a variety of ways to produce entertaining dishes! 
Education: There are, of course, positive benefits to children, whether they become members of the élite or not. Many people have believed for a long time that, through sport, children can learn new physical and social skills, develop self-confidence, and meet challenges (see Shields and Bredemeier, 1995). It also allows them to prepare for adult recreation patterns that may last throughout their lives. This can have the effect of promoting a healthy population - and reduce costs to government health care programmes. This may be increasingly important as western society makes greater attempts to counter the spread of obesity.

Successful sports performers add status to their clubs, sports federations and governments, and can be important sources of income for them. All of this is seductive to those who promote sport for young people they can claim altruistic motives. However, those who are charged with coaching young people must make choices about the relative importance of their values in relation to their coaching duties and decide what the important outcomes should be.

\section{SPORTING VALUES}

In light of these arguments, coaches are faced with a number of dilemmas when they begin coaching children. Several dilemmas are summarised in Table I.

Let us look briefly at these dilemmas. The conflict between élitist and populist goals suggests two different approaches to coaching sessions and selection. The elitist position, for example, would give preference to the best performers, while the populist would ensure that all children got equal treatment, playing time, training opportunities etc. The nationalist position is to promote and develop success in one's own nation, region, club, or school at the expense of others. It has become the norm for nations to put considerable resources into junior sports programmes in order to achieve success in the international arena. However, many international governing bodies recognise that in order to promote their sport the strong must support the weak; so we see programmes of international development to nations with fewer resources or little history in the particular sport. The current strategy of the International Rugby Board is a case in point. A strong competitive programme is essential for the growth and survival of any sport; competition for audiences lies between sports rather than within them.

The promotion of nationalist objectives, however, seems increasingly to drive government policies in sport. We might suggest that nationalism is akin 
to commercialism in promoting a particular product and is concerned with the élite performer. But most youth sport coaches deal primarily with those children who have no national expectations or commercial value. Their athletes will strive to become as good as they can, to have fun, to meet a challenge, and to be with friends (see Brustad, 1993 for review). Perhaps most coaches, therefore, should be concerned with helping them meet those goals.

Table I. Dilemmas facing coaches

\begin{tabular}{llll}
\hline Goals & Élitist & Vs & Populist \\
& Nationalist & Vs & Universalist \\
& Commercial & $V_{s}$ & Charitable \\
& Education & $V_{s}$ & Performance \\
& Personal achievement & $V_{s}$ & Superiority over others \\
& Fairplay & $V_{s}$ & Winning \\
\hline Needs & Child & $V_{s}$. & Coach \\
& Child & Vs & Club \\
& Child & Vs. & Sport \\
& Child & $V_{s}$ & National / sponsor's interest \\
\hline Values & Benevolence & Vs. & Power / Status \\
\hline
\end{tabular}

The key seems to lie in making the choice between Education and Performance. This dilemma forces decisions about whether it is more important to emphasise goals concerned with getting better or goals concerned with being the best. So, is it more important to be fair or to win? Is it more important to concentrate on becoming more skilful or to win? Is it more important to promote the development of the child or the development of the sport, club, or nation? The answers to these questions reflect the primacy given to the needs of the children we coach or to various sport providers and sponsors. But it should not be concluded that these answers are, necessarily, mutually exclusive. Essentially, the dilemmas that coaches have to face are resolved by their value systems because, in the end, all our choices are defined by our values. Coaches who place the welfare of others above personal power and status will choose to develop children's performance. Coaches who think that power, prestige, and status are more important will choose to win above all. Nevertheless, these distinctions are not made easily. Such has been the expansion of sport as a form of business and entertainment during the relatively recent past that for those youngsters who succeed the future is often assured. However, for all those who succeed, many fail, in relative terms. A former director of the German Sports Institute in Leipzig once said that they worked on ratio of 100-1. To identify and develop one champion they needed to start from a base of 100 (Dietrich, 1998, personal communication).

Turning to the questions of whose needs are met, you will see that I suggest that there are conflicts between the needs of the child and the coach, 
club, sport, nation or sponsor. Children are particularly vulnerable to the influence of others and susceptible to manipulation by social forces of which they are unaware. Yet, their needs must be paramount if we are to adhere to Kant's moral imperative and not use children to satisfy our own ambitions. The decisions may be very sensitive when dealing with talented children. How can you help them to develop those talents to the maximum while at the same time not threatening their futures should they eventually fail in their chosen sport either through lack of ability or circumstance, such as injury?

This leads us to the final category of values in which benevolence is contrasted with power and status. Schwartz (1992) has developed a model of values based upon two basic motivational dimensions: Openness to Change to Stability and Self-interest to Concern for Others. The model locates different value dimensions about the axes such that domains, groups of values that are compatible with each other are adjacent and those that conflict with each other are opposite to each other. The model draws attention, therefore, to the difficulty in reconciling conflicting values. In this case, benevolence, which shows a concern for others, conflicts with the pursuit of power and status, which exemplify self-interested values.

In discussing his model Schwartz (1992) points out that it is possible for apparently conflicting values to be held within the same belief system because conflicts only arise infrequently in everyday life. However, I would suggest that conflicts of value arise commonly in sport. Schwartz' (1992) model indicates that the pursuit of success is entirely compatible with the pursuit of pleasure and with the pursuit of power, status and prestige, which are located in adjacent areas. They are set against the more altruistic value domains that identify the welfare of others as paramount. Yet, we like to think that sport provides a good environment for the development of altruism, fairplay, sportsmanship and so on. However, we cannot ignore the fact that sport, by its very nature is self-interested - the purpose is to demonstrate superiority, power over others, and the status that is associated with success. At the same time, it is conducted according to an agreed set of rules to which all competitors are expected to perform. Nevertheless, élite sport seems increasingly to demand that altruistic values are set aside in favour of selfinterested values, and the search for potential élite performers leads to a culture in which the weak go to the wall.

We do not know a great deal about the values of the majority of coaches who work with children but we do have some information from adolescent athletes. They think that the most important things in sport are enjoyment, showing achievement by getting better, and playing fairly. They do not appear to think that winning is as important (Mielke and Balke, 1995; Lee et al., 2000). They also think that the most important people who influence 
their thinking are their coaches (Lee and Balchin, 1996). This suggests that those coaches transmit values that show their concern for others.

\section{PROVIDING GOOD COACHING}

\section{a) Knowing your values}

So, how can we do the best job for young athletes? Most importantly coaches should be clear about their values; they must decide what is most important to them in coaching children. Placing the children's needs first does not mean that sport need be simply an extension of unstructured play. It means providing an environment in which children can realise their potential and learn more about themselves as human beings. In short, helping them to grow up. If we help that process we may also be able to help them become great athletes. But remember - if winning is the only important thing in the coach's mind and in the children's minds then when they lose there is nothing left! Winning is not entirely in the control of either coaches or athletes - the opposition may be just too good! So getting children to concentrate on getting better at their skills is more productive in the long run. It will keep more children interested, allow them to deal with losing, and enable them to set attainable targets. Then they are more likely to enjoy the sport and come back for more.

To help you to be clear about your own values let me turn to some outcomes of a research programme we have been conducting at Brighton in the last few years. Building upon the work of Schwartz and Rokeach we developed a questionnaire to measure values among young athletes (Lee et al., 2000). Then we examined the relationship between values and motivational orientation. To do this we used three groups of values Competence, Moral, and Status values - that seemed to underlie positive and negative attitudes in sport. Thus, we can ask a short series of questions about which is most important when set against each of the others. For example: Do I think it is more important to be good than fair? Do I think it is more important to be a winner than good at the sport? and, finally, do I think it is more important to be a winner than fair? The answers to these questions will influence how you coach and the model you present to your athletes. Of course, it may not be that these values are necessarily mutually exclusive. It may be possible to accommodate a desire to be competent, to be fair, and to be a winner, but I would suggest that it demands a clarity of understanding and a willingness to explore the values that guide one's behaviour with honesty and consistency. 
We have been able to show that, among young athletes, the values of competence, morality, and status are important in determining pro-social and anti-social attitudes (Lee et al., 200I). The pro-social attitudes were exemplified by a respect for the conventions of sport and commitment; antisocial attitudes by cheating and gamesmanship'. Furthermore, the effects of competence and status values operate through the dominant motivational perspectives that athletes use to assess their success or failure.

The interpretation of success seems to be made by reference to one of two styles known as task motivation and ego motivation. Those who adopt a task perspective see success in terms of self-referenced criteria such as improvement and the excellent performance of sporting skills. Those who adopt an ego perspective typically see success in terms of demonstrating superiority over others. winning. and they focus upon outcomes rather than performance. This might be summarised by distinguishing between 'doing' one's best as opposed to 'being' the best. These are not necessarily mutually exclusive; the best competitors may exhibit characteristics of both and be able to switch from one state to another as the occasion demands.

In our research, we have shown a pattern of relationships among values, motivational perspectives, and attitudes among young athletes. First, sociomoral values directly effect both positive and negative values. Second, competence values determine positive attitudes through the mechanism of a task orientation to the interpretation of success. Third, status values determine negative attitudes through the mechanism of an ego orientation to the interpretation of success (Lee et al., 200 I). Therefore, we could expect that if we can develop values in young athletes that emphasise pride in performance, development of skills, and a desire to improve, then the dominant motivational perspective will be one in self-referenced criteria are used to determine success and result in more positive attitudes towards participation. If, however, we place more emphasis on the status and prestige to be gained from sporting success we will encourage comparative criteria to determine success - we must be better than others in order to be good. This may then result in negative attitudes to sport participation; that is, a resort to cheating and gamesmanship.

\section{b) Putting it into practice}

Having attempted to clarify our own values, identified what we are really trying to achieve when we coach children - and knowing that coaches are major contributors to the values that children adopt in sport (Lee and Balchin, 1996)

I Gamesmanship is a term that refers to manipulation of the rules, officials or opponents to gain an unfair advantage. Stephen Potter first articulated it in his book 'Theory and practice of gamesmanship, or the art of winning without actually cheating.' London: Hart-Davis, 1947. 
- we need to ask how do we actually transmit our values to others and help them to develop them. The transmission of values is a subtle and complex process but one that cannot be avoided. We should also be aware that it does not proceed in one direction. Our values are subject to examination and influence by the everyday interaction with others, be they children or other adults (Coles, 1998). We may find that in coaching children the values that we hold are challenged by the behaviour of others involved in the process parents, children, other coaches, and administrators. This very challenge forces either a defence of, or a change in, often deeply held beliefs.

So, what can we learn from that? Perhaps it is important to be aware of those beliefs and understand how they are translated into action such that the youngsters we work with can see them in practice. If we believe that winning competitions is the primary reason for doing sport then we will encourage only winners, pursue competitive success at all times, reject those who are improving but not quickly enough, and take advantage of every situation. If we believe that sport is also concerned with developing young people to do their best, we will reward improvement, effort, and commitment. We will encourage every athlete - not just the best - set individual targets of performance, and support our athletes even when they fall short. If we value fairplay and sportsmanship we will demonstrate it in all that we do; show respect for players, opponents, officials, the rules of the game (Vallerand et al., 1997) and demand the same of our players. We will not tolerate cheating or foul play or even gamesmanship.

The value of winning is an expression of the primacy of self-interested values interpreted as a demonstration of superiority over others. This seems to be a logical requirement of an élitist philosophy and herein lies a dilemma for the sports coach. Top professional and international sport depends upon, increasingly, an élitist philosophy and value system, yet very few of the children that we a work with can achieve or even aspire to that level of excellence. Therefore, coaches of young athletes must make a decision about how to use their resources to the best effect. Whether or not their primary purpose is to provide the material for sport as a business and for national teams? If so, it will require them to sift through the material available to them and to discard those who do not make the grade. If not, the alternative seems to be to try to help all their athletes to develop to the limit of their potential and then decide for themselves how far they wish to, or can, go.

These need not be mutually exclusive. It is possible to develop inclusive sports programmes that encourage children of all levels of ability to develop as far as possible while at the same time encouraging the most talented to progress further without it being at the expense of the less able (see for example De Knop et al., 1994). However, it may not be possible for individual 
coaches to accommodate both groups at the same time. Some coaches may be better suited to working with the most talented while others may be better suited to working with the less able or the beginners. Knowledge of one's own strengths and weaknesses may be a key to understanding one's values and making the most of ones' abilities.

It seems unarguable that coaches should see that children enjoy their sporting experiences and encourage them to return for more. Research (e.g. Smith et al., 1979; Lee and Austin, 1988; Theeboom et al., 1995) has shown that this can best be achieved if coaches:

- Establish good relationships with the children.

- Are both firm and fair.

- Give positive feedback rather than negative.

- Teach skills.

- Keep a sense of humour.

- Get to know each child individually.

- Set challenging but reachable targets.

- Focus on doing as well as you can rather than winning.

By doing these things, children are encouraged to be responsible for their own learning, gain a sense of achievement, and will have fun. When that happens then we can expect them to return to develop their skills and perhaps become committed to the pursuit of excellence. Then sport will reap the rewards!

\section{CONCLUSION}

The argument that I have put in this paper is that coaches, and others responsible for the provision of children's sport, assume a position where their values must be examined and tested. This means that they must examine their personal values within the wider sphere of society and understand the roles that sport takes in the life of a nation and the individuals who comprise it. Thus, each of us must confront our own value system and define our own particular role in the sport system. Clearly, the importance of sport to national identity and to commerce throughout the world has grown remarkably since the days of Baron de Coubertin and the sport industry requires a constant supply of talented athletes. Nevertheless, it is not necessary that all children who do sport can, or would wish to, aspire to those levels. For most, sport provides a means of learning about themselves, of developing recreational, social, and physical skills, and perhaps of learning to become good citizens (see Telama and Liukonnen, 200I). Each of us has to make the decision of where we fit in to the overall picture. Unfortunately sport also provides an opportunity to violate the moral imperative; managers need to find good 
athletes to meet their own ambitions and athletes need to find good coaches to enable them meet their own goals. When we are dealing with children, however, we are in a position of power and authority that should not abused either by unfairly holding them back, prematurely advancing them, or by unfairly rejecting them. When making the important choices that face us let us hope that we can do so with the best interests of our young athletes at heart.

\section{REFERENCES}

Brustad RJ (1993). Youth in sport: Psychological considerations. In RN Singer, M Murphy, LK Tennant (eds): Handbook of Research in Sport Psychology. New York: Macmillan

Bouchard C (1999). Genetics and the future of sport. In R Malina (Ed): Youth Sports in the 2 I st Century. Institute for the Study of Youth Sports. Michigan State University. East Lansing. Michigan. 23-26th May, Lansing MI, Michigan State University. (Abstract).

Chataway C, Goodhart R (1968). War Without Weapons. London: Allen

Coles R (1998). The Moral Intelligence of Children. London: Bloomsbury.

De Knop P, Wylleman P, Theeboom M, De Martelaer K, Van Puymbroek L, Wittock H (1994). Youth Friendly Sport Clubs. Brussels: VUBPress.

Dietrich M (1998). Personal communication.

Dixon (2000). A justification of moderate patriotism in sport. In T Tannsjo, C Tamburrini (Eds): Values In Sport. London: E \& FN Spon.

Franke WW, Berendonke B (1997). Hormonal doping and the androgenization of athletes: A secret program of the German Democratic Republic government. Clinical Chemistry. 43.7. I262-1279.

Glassford G (1989). Sport and educational values: New stakes as the year 2000 draws near. In F Landry (Ed): Sport in The Third Millenium. Quebec: Presses de l'Université de Laval

Lee MJ, Austin H (1988) Dimensions of coaching behaviour in children's sport. Report to the Research Committee of the National Coaching Foundation. Headingley. Leeds. Yorkshire. England.

Lee MJ, Balchin N (1996). Social influences on values in young athletes. Journal of Sport Sciences. 15. 92-3.

Lee MJ, Whitehead J, Balchin N (2000). The measurement of values in youth sport: Development of the Youth Sport Values Questionnaire. Journal of Sport and Exercise Psychology. 22. 4. 307-326.

Lee MJ, Whitehead J, Ntoumanis N, Hatzigeorgiadis A (200 I). Goal orientations as mediators of the influence of values on sporting attitudes in young athletes. Paper presented at the $10^{\text {th }}$ World Congress of Sport Psychology. Skiathos. Greece. May $30^{\text {th }}$.

Mielke R, Balke S (1995). Structure and preferences of fundamental values of young athletes. Do they differ from non-athletes and from young people with alternative leisure activities. International Review of the Sociology of Sport. 30. 3-4. 419-437.

Morgan WJ (2000) Sport as the moral discourse of nations. In T Tannsjo, C Tamburrini (Eds): Values in Sport. London: E \& FN Spon. 
Munthe $C$ (2000). Selecting champions: Making winners in the age of genetic technology. In T Tannsjo, C Tamburrini (Eds): Values in sport. London: E \& FN Spon.

Potter S (1947). Theory and Practice of Gamesmanship. or The Art of Winning Without Actually Cheating. London: Hart-Davis.

Rokeach M (1973). The Nature of Human Values. New York: The Free Press of Glencoe.

Schwartz S (1992). Universals in the structure and content of values: Theoretical advances and empirical tests in 20 countries. In MP Zanna (Ed): Advances in Experimental Social Psychology. Vol. 25. New York: Academic Press.

Smith RE, Smoll FL, Curtis W (1979) Coach effectiveness training: A cognitivebehavioral approach to enhancing relationship skills in youth sport coaches. Journal of Sport Psychology. 1. 59-75.

Sport England (2002) Information sheet: Basic facts about sport. London: Sport England. (http//www.sportengland.org/resources/info/basic.htm).

Tannsjo T (2000). Is it fascistiod to admire sports heroes? In T Tannsjo, C Tamburrini (Eds): Values in Sport. London: E\& FN Spon.

Tannsjo T, Tamburrini C (2000). Values in Sport. London: E \& FN Spon.

Tasmanian State School Sport Council (1983). A child is not a little adult: modified approaches to Australian sport. Hobart: Division of Recreation. Education Department. 